Environ. Biosafety Res. 5 (2006) 67-75

(C) ISBR, EDP Sciences, 2006

DOI: $10.1051 / \mathrm{ebr}: 2006019$

\title{
Transgenic oilseed rape along transportation routes and port of Vancouver in western Canada
}

\author{
Yasuyuki YOSHIMURA ${ }^{1}$, Hugh J. BECKIE ${ }^{2 \star}$ and Kazuhito MATSUO ${ }^{1}$ \\ ${ }^{1}$ National Institute for Agro-Environmental Sciences, Tsukuba, Ibaraki 305-8604, Japan \\ ${ }^{2}$ Agriculture and Agri-Food Canada, Saskatoon Research Centre, Saskatoon, Saskatchewan, Canada
}

\begin{abstract}
The occurrence of transgenic herbicide-resistant oilseed rape (Brassica napus) in ruderal (non-crop disturbed) areas has not been investigated previously in Canada. The primary objective of this study was to document their occurrence in two main ruderal areas (along railways and roads) in the province of Saskatchewan, where half of all oilseed rape is grown, and at the port of Vancouver, British Columbia on the west coast of Canada, where most oilseed rape destined for export is transported by rail. During the 2005 growing season, leaf samples of oilseed rape plants were collected at randomly-selected sites along railways and roads across Saskatchewan ecoregions and at Vancouver; infestation area, density, and plant height of oilseed rape were measured at each site. The presence of the glyphosate and glufosinate resistance traits was determined using test strips. The infestation area of oilseed rape, averaged across 155 sampled sites in the Saskatchewan survey, was markedly smaller in populations along railways than roads; in contrast, infestation area averaged across 54 sites in the Vancouver survey was greater for populations along railways than roads. In both surveys, mean plant density was greater for populations found along railways than roads. Two-thirds of oilseed rape plants sampled across Saskatchewan ecoregions and at Vancouver were transgenic, although the relative proportion of plants with the glyphosate or glufosinate resistance trait varied between surveys. Frequency of occurrence of transgenic plants in ruderal areas was similar to the proportion of the oilseed rape area planted with transgenic cultivars in the recent preceding years. A single transgenic $B$. rapa $\times$. napus hybrid was found along a road in Vancouver, confirming the relatively high probability of hybridization between these two Brassica species. With current control measures, transgenic oilseed rape populations may persist and spread in these ruderal areas.
\end{abstract}

Keywords: Brassica napus / canola / gene flow / herbicide resistance / oilseed rape / ruderal / transgenic crop

\section{INTRODUCTION}

In 2005, 5.5 million ha of canola (Brassica napus L. with $\leq 2 \%$ B. rapa L.) were grown in western Canada, of which half was in the province of Saskatchewan (Beckie et al., 2006; Statistics Canada, 2005). Transgenic herbicideresistant (HR) oilseed rape cultivars were introduced commercially in Canada in 1995. Over $80 \%$ of the oilseed rape area is now transgenic, resistant to the non-selective herbicides glyphosate $(50 \%)$ or glufosinate $(32 \%)$ (Beckie et al., 2006).

The distribution and abundance of volunteer oilseed rape across western Canada agroecoregions (defined by climate, natural vegetation, soils, and land use; Agriculture and Agri-Food Canada, 2003) have been well documented by field surveys. Volunteer oilseed rape is more common in fields in the sub-humid Parkland region, where oilseed rape is grown most frequently in crop rotations, than in fields in the semi-arid Grassland region. Volunteer oilseed rape (mainly HR) was ranked 12th among weed species in relative abundance (composite index based on field frequency, field uniformity, and plant density) in weed surveys conducted in the early 2000s (Leeson et al., 2005).

The HR traits in oilseed rape have facilitated investigations of intra- and interspecific pollen-mediated gene flow. In oilseed rape where outcrossing averages $30 \%$, and where more than one HR trait has been developed, pollen-mediated gene flow can result in multiple-HR (i.e., gene-stacked) volunteers. Multiple-HR

\footnotetext{
* Corresponding author: beckieh@agr.gc.ca
} 
oilseed rape volunteers were first documented in the late 1990s (Hall et al., 2000). A subsequent study quantified the frequency and distance of pollen-mediated transgene flow between glyphosate- and glufosinate-HR oilseed rape fields in Saskatchewan, resulting in double-HR volunteers (Beckie et al., 2003).

The frequency of gene flow from oilseed rape to four weedy relatives, bird's rape (Brassica rapa L.), wild mustard (Sinapis arvensis L.), dog mustard (Erucastrum gallicum (Willd.) O.E. Schulz), and wild radish (Raphanus raphanistrum L.) was assessed in greenhouse or field experiments, and actual rates were measured in commercial fields in Canada (Warwick et al., 2003). Bird's rape has a limited distribution as an agricultural and/or ruderal weed in eastern Canada (Warwick et al., 2003). Hybridization between bird's rape and oilseed rape occurred in two field experiments (7\% frequency), and in populations in commercial fields in Québec (14\%). In contrast, gene flow between oilseed rape and wild radish was rare. A single hybrid was detected in 32821 seedlings from a field experiment. No wild mustard or dog mustard $\times$ oilseed rape hybrids were detected from commercial fields in Saskatchewan. The presence of an HR transgene in $B$. rapa $\times$ oilseed rape hybrids results in little or no fitness cost (Snow et al., 1999). Current studies are determining the extent of pollen flow from glyphosateHR oilseed rape to other Brassica crops, including oriental mustard (Brassica juncea (L.) Czern.) and B. rapa canola (B. rapa with low levels of glucosinolates and erucic acid). Gene flow to both crops has been documented up to $200 \mathrm{~m}$ (Warwick, 2005; G. Séguin-Swartz et al., unpublished data).

Although the occurrence of transgenic-HR oilseed rape volunteers in cropland has been investigated in Canada previously, the prevalence of such plants in natural (unmanaged) or ruderal (non-crop disturbed) areas, such as along railways and roads, is unknown. HR oilseed rape volunteers are not considered noxious weeds, nor invasive in natural ecosystems (Beckie et al,. 2001). Where herbicides are used in ruderal areas, the potential invasiveness of HR crops, such as oilseed rape, may be greater. For example, the use of glyphosate or ALS inhibitor herbicides at oilwell sites or along railways or roads adjacent to cropland might result in a lack of control of HR oilseed rape. Previous studies have shown little difference in fitness among non-HR, single-HR, or multiple-HR oilseed rape in the absence of herbicide selection, suggesting HR oilseed rape volunteers do not have any greater capacity than non-HR plants to invade ruderal or natural areas (e.g., Simard et al., 2005). Those findings and the results of Beckie et al. (2004) indicate that single- or multiple-HR oilseed rape are not more weedy than non-HR plants in ruderal sites where they can be controlled by herbicides of alternative modes of action.

Gene flow via seed has the potential to influence agriculture temporally and on a much larger scale than gene flow via pollen (Hall et al., 2003). Most oilseed rape plants along roads are likely the result of seed spillage during transportation of seeding or harvesting equipment or harvested crop seeds from field to a farmer's grain storage bin, or from field or bin to an inland grain elevator or oilseed rape-processing facility. The average radius serviced by a northern Great Plains (prairie) elevator was $24 \mathrm{~km}$ in the 1990s (Beckie et al., 1999). With significantly fewer elevators across the prairies today, seed is now transported by truck over much longer distances. Oilseed rape along railways may be the result of spillage or seed movement from adjacent roads or fields. Japan is the largest buyer of Canadian oilseed rape seed (Canola Council of Canada, 2006); therefore, oilseed rape seed destined for export is often transported westward by railway to port grain terminals at Vancouver, British Columbia for shipment across the Pacific Ocean.

Populations of transgenic plants in ruderal areas can result in increased persistence and spread of transgenes in the environment, with implications for identity preservation of crops, including those grown organically, and weed control in nearby fields. The primary objective of this study was to document the occurrence of transgenic oilseed rape in the two primary ruderal areas - along roads and railways - in Saskatchewan and at the port of Vancouver (Fig. 1). A secondary objective was to assess transgene presence in cultivated and weedy relatives of oilseed rape (i.e., hybridization) in these areas.

\section{RESULTS}

Averaged across the 155 ruderal sites in Saskatchewan where oilseed rape was found, the mean infestation area was markedly smaller for populations along railways than roads (Tab. 1). However, mean plant density was greater for populations along railways than roads. Mean plant height, similar to infestation area, was less in populations along railways than roads (Tab. 1). Infestation area and density of the cultivated or weedy relatives were less than that of oilseed rape (roadsides). These species were found more often along roads or in areas where railways and roads were in close proximity, such as railway crossings or near elevators, than along railways (data not shown). Wild mustard, oriental mustard, dog mustard, and B. rapa canola were found in order of decreasing frequency of occurrence, based on the number of sites where they 


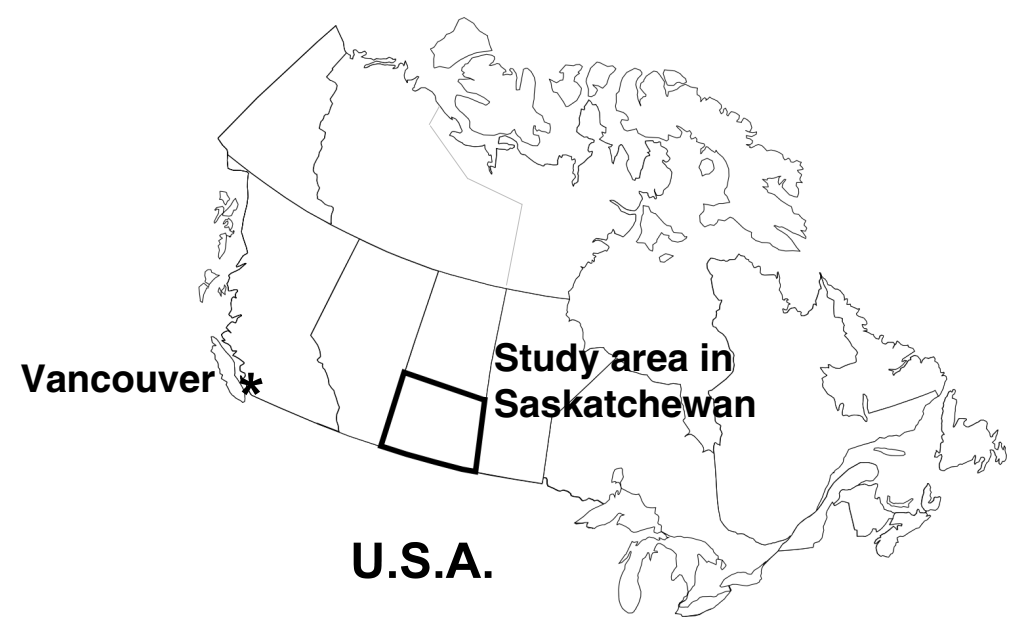

Figure 1. Study areas: port of Vancouver, British Columbia and agricultural region of Saskatchewan, Canada.
Table 1. Mean infestation area, density, and plant height of oilseed rape and its relatives in ruderal areas of Saskatchewan, Canada in 2005 (mean \pm SE).

\begin{tabular}{lcccc}
\hline \hline Species & $\begin{array}{c}\text { Sites } \\
(\text { no. })\end{array}$ & $\begin{array}{c}\text { Infestation } \\
\text { area }^{\mathrm{a}} \\
\left(\mathrm{m}^{2}\right)\end{array}$ & $\begin{array}{c}\text { Density }^{\mathrm{a}} \\
\left(\text { no. }^{-2}\right)\end{array}$ & $\begin{array}{c}\text { Plant } \\
\text { height }^{\mathrm{b}} \\
(\mathrm{cm})\end{array}$ \\
\hline Oilseed rape (railway) & 63 & $190 \pm 69$ & $55.9 \pm 15.3$ & $26.5 \pm 1.1$ \\
Oilseed rape (roadside) & 92 & $2170 \pm 934$ & $16.9 \pm 4.0$ & $39.2 \pm 1.1$ \\
Oriental mustard & 72 & $806 \pm 469$ & $5.9 \pm 1.3$ & $48.2 \pm 1.5$ \\
B. rapa canola & 7 & $4 \pm 2$ & $2.5 \pm 1.1$ & $42.1 \pm 6.3$ \\
Dog mustard & 16 & $20 \pm 4$ & $6.3 \pm 1.8$ & $33.6 \pm 2.5$ \\
Wild mustard & 91 & $285 \pm 100$ & $7.9 \pm 2.9$ & $44.7 \pm 1.4$ \\
\hline
\end{tabular}

${ }^{a}$ Maximum infestation area of oilseed rape (Brassica napus) was $3500 \mathrm{~m}^{2}$ (railway) and $80000 \mathrm{~m}^{2}$ (roadside); maximum density of oilseed rape was 672 plants $\mathrm{m}^{-2}$ (railway) and 240 plants $\mathrm{m}^{-2}$ (roadside).

${ }^{b}$ Based on measurements of 210 oilseed rape plants (railway), 273 oilseed rape plants (roadside), 192 oriental mustard (B. juncea) plants, 13 B. rapa canola plants, 45 dog mustard (Erucastrum gallicum) plants, and 244 wild mustard (Sinapis arvensis) plants.

occurred. Mean infestation area of oriental mustard and wild mustard was significantly greater than that of dog mustard and $B$. rapa canola. Mean plant density was similar among oriental mustard, wild mustard, and dog mustard populations, and greater than that of $B$. rapa canola. As expected, variance in infestation area or density of oilseed rape (Tab. 1 and Fig. 2) and its relatives was relatively high, reflecting site heterogeneity.

At the port of Vancouver, both infestation area and density of oilseed rape were greater for populations along railways than roads (Tab. 2). Eight of the 26 roadside sites had only a single oilseed rape plant. Similar to results in Saskatchewan, mean height of oilseed rape growing along railways was less than that along roads. Both oilseed rape plant density and infestation area declined exponentially with increasing distance from the nearest grain terminal (Fig. 3). However, plants were found in sparse populations up to $15 \mathrm{~km}$ from the nearest grain terminal.

The cultivated and weedy relatives of oilseed rape were found mostly on roadsides and not along railways at Vancouver (data not shown). Wild radish was found most frequently (16 sites) and $B$. rapa canola least frequently (6 sites) (Tab. 2). All four species, however, were found less frequently than oilseed rape. Infestation area of populations of these species was greater than that of oilseed rape along roads; with the exception of wild mustard, densities were similar to roadside oilseed rape volunteers. Density of wild mustard and infestation area of oriental mustard were greatest among the weedy or cultivated relatives of oilseed rape for these respective attributes.

The glyphosate and glufosinate resistance trait were found in 34 and $30 \%$, respectively, of the 300 oilseed rape plants sampled across Saskatchewan ecoregions (Tab. 3). The glufosinate resistance trait tended to occur less frequently in plants along roads than railways. Transgenic oilseed rape plants were frequently found in ruderal areas in all four ecoregions, not only in the traditional oilseed rape-growing areas of the sub-humid Parkland region (Aspen Parkland and Boreal Transition ecoregions) (Fig. 4). Oilseed rape is not commonly grown in the Mixed Grassland ecoregion because of frequent hot, dry weather conditions; most of the southwestern area of this ecoregion is rangeland. However, in more northeasterly areas of this ecoregion where annual cropping occurs, increased precipitation during recent growing seasons have encouraged farmers to include oilseed rape in their crop rotations. Conversely, limitations to oilseed rape 

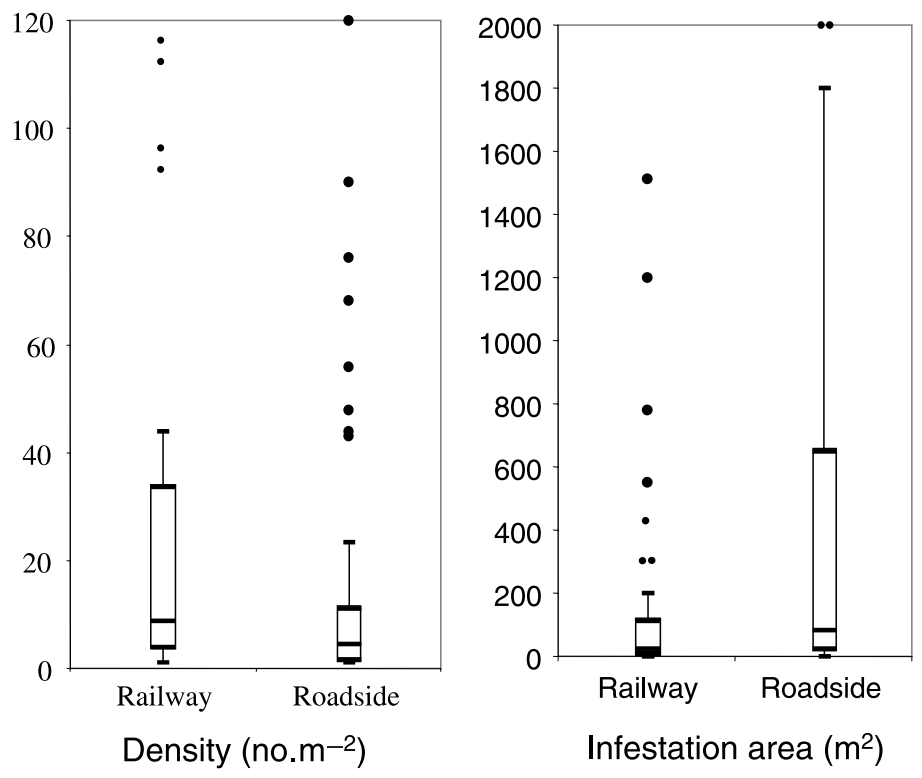

Figure 2. Box plots of density and infestation area of oilseed rape in ruderal areas of Saskatchewan, Canada in 2005 (line in the box denotes median value, upper edge (hinge) of the box denotes 75th percentile, lower hinge denotes 25 th percentile, vertical lines (whiskers) extend to a maximum of 1.5 times the inter-quartile range (between 25th and 75th percentiles); some extreme outliers not shown).
Table 2. Mean infestation area, density, and plant height of oilseed rape and its relatives at the port of Vancouver, Canada in 2005 (mean \pm SE).

\begin{tabular}{lcccc}
\hline \hline Species & $\begin{array}{c}\text { Sites }^{\mathrm{a}} \\
(\text { no. })\end{array}$ & $\begin{array}{c}\text { Infestation } \\
\text { area } \\
\left(\mathrm{m}^{2}\right)\end{array}$ & $\begin{array}{c}\text { Density } \\
\left(\text { no. }^{-2}\right)\end{array}$ & $\begin{array}{c}\text { Plant } \\
\text { height }^{\mathrm{b}} \\
(\mathrm{cm})\end{array}$ \\
\hline Oilseed rape (railway) & 28 & $105 \pm 43$ & $118 \pm 37$ & $19.3 \pm 1.8$ \\
Oilseed rape (roadside) & 26 & $3 \pm 1$ & $5.7 \pm 1.8$ & $38.1 \pm 3.0$ \\
Oriental mustard & 9 & $37 \pm 33$ & $3.8 \pm 0.8$ & $63.6 \pm 9.6$ \\
B. rapa canola & 6 & $6 \pm 2$ & $3.4 \pm 2.4$ & $84.8 \pm 8.3$ \\
Wild radish & 16 & $19 \pm 7$ & $6.2 \pm 1.7$ & $67.7 \pm 6.2$ \\
Wild mustard & 10 & $12 \pm 5$ & $39.2 \pm 36.2$ & $46.6 \pm 11.7$
\end{tabular}

${ }^{\mathrm{a}}$ The number of sites having a single plant were the following: oilseed rape (Brassica napus) (railway), 1; oilseed rape (roadside), 8; oriental mustard (B. juncea), 1; B. rapa canola, 3; wild radish (Raphanus raphanistrum), 3; and wild mustard (Sinapis arvensis), 5. b Based on measurements of 45 oilseed rape plants (railway), 60 oilseed rape plants (roadside), 14 oriental mustard plants, 9 B. rapa canola plants, 24 wild radish plants, and 13 wild mustard plants.

production in the Boreal Transition ecoregion include forest areas, soils not suitable for annual cropping, and a relatively short growing season.

In contrast to the test strip results from the Saskatchewan survey, occurrence of oilseed rape plants with the glyphosate resistance trait was markedly greater than those with the glufosinate resistance trait at the port of Vancouver (Tab. 3). Similar to Saskatchewan results, about one-third of plant samples did not have either transgene, and no oilseed rape sample had both transgenes. Most transgenic oilseed rape plants were found in close proximity to the port grain terminals along the north and south shores of Burrard Inlet (Fig. 5).

Among the cultivated (163 samples) and weedy relatives of oilseed rape (223 samples), only one plant originally identified as B. rapa possessed the glyphosate resistance trait. Subsequent molecular analysis, however, confirmed that the plant was a $B$. rapa $\times B$. napus hybrid. It had both $B$. rapa and B. napus AFLP markers (data not shown). The transgenic hybrid was found along a road east of the airport (Fig. 5).

\section{DISCUSSION}

In the prairies, the thick bed of gravel/crushed rock supporting the rails and normally well-established perennial grass and legume species growing adjacent to the gravel bed generally creates a more restricted habitat for weed emergence and growth than along gravelled primary (grid) roads. Along these roads (on the surface edge or adjacent ditch), weeds can grow in bare-soil areas where planted perennial grass and legume species have not established. Along recently-constructed roads where the ditch area has been seeded with perennial species, weeds are often abundant until such plants become established. Once established, however, they compete well against weedy species; in addition, ditches along primary roads are usually mowed once a year in late summer or autumn, which aids weed control. 


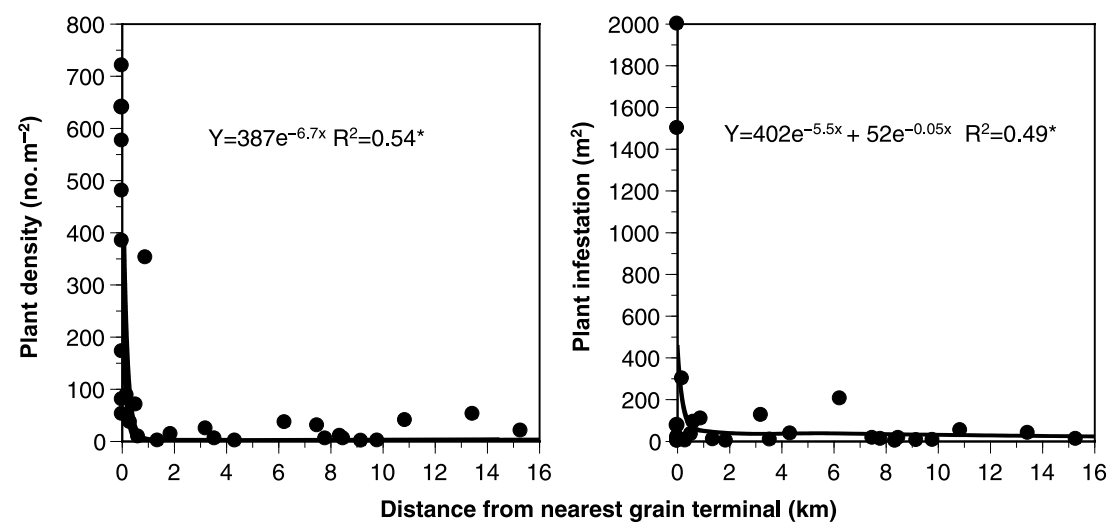

Figure 3. Exponential decline in oilseed rape density and infestation area with increasing distance from the nearest grain terminal at the port of Vancouver, Canada in 2005 (*: coefficient of determination $\left(\mathrm{R}^{2}\right)$ significant, $P<0.05$ ).
Table 3. Percentage of oilseed rape plants sampled in ruderal sites across Saskatchewan ecoregions and at the port of Vancouver, Canada with the glyphosate (RR) or glufosinate (LL) resistance trait.

\begin{tabular}{lcccc}
\hline \hline Species & $\begin{array}{c}\text { Plants } \\
\text { sampled } \\
\text { (no.) }\end{array}$ & RR trait LL trait & $\begin{array}{c}\text { Not } \\
\text { detected }\end{array}$ \\
Saskatchewan ecoregions & & & & \\
Railway & 120 & 34 & 38 & 28 \\
Roadside & 180 & 33 & 25 & 42 \\
Total & 300 & 34 & 30 & 36 \\
Port of Vancouver & & & & \\
Railway & 46 & 48 & 22 & 30 \\
Roadside & 35 & 37 & 23 & 40 \\
Total & 81 & 43 & 22 & 35 \\
\hline
\end{tabular}

However, there are numerous areas along railways where perennial plants are not well established and annual plants, such as oilseed rape, can colonize. Thus, although the infestation area of oilseed rape populations may be smaller along railways than roads, plant densities can be greater. General lack of mowing or other means of weed control along railways allows weeds to complete their life cycle and annually replenish the seed bank. Greater intraspecific competition at the higher plant densities observed along railways than roads likely contributed to reduced individual plant vigor, as assessed by height.

The greater frequency of occurrence of cultivated and weedy relatives of oilseed rape along roads than railways is likely partially the result of the western Canadian grain transportation system or equipment movement. Seeds of the harvested crop are transported by truck from field to storage bin, or from field or bin to inland grain elevator or processing facility. These seedlots usually contain weed seeds. Seeds may blow off uncovered grain truck boxes or fall through box crevices. In addition, crop or weed seeds may fall off combine harvesters or seeders when moving such equipment. At elevators or inland terminals, weed seeds are removed from seedlots before loading onto rounded-steel rail cars. However, $100 \%$ weed seed removal is unrealistic. Along railways, some light weed seeds may also be wind-blown from adjacent fields.

The general area across Saskatchewan ecoregions where B. rapa canola, dog mustard, and wild mustard were found and their relative frequency of occurrence correspond with the results of a recent field survey of weeds in Saskatchewan (Leeson et al., 2003). In that 2003 survey, wild mustard ranked $15 \mathrm{th}$, dog mustard 63rd, and volunteer B. rapa canola 91 st in relative abundance. In the survey reported herein, oriental mustard volunteers (not differentiated from other mustard species in the field survey in 2003) were usually found in the semi-arid Grassland ecoregions (data not shown) where the crop is best adapted. $B$. rapa canola is usually grown on a small hectarage in the northern-most areas of the Parkland region because of its short growing season degree-day requirement.

At the port of Vancouver, greater infestation area and density of populations of oilseed rape along railways than roads were expected, given that oilseed rape is transported from the prairies to the port terminals exclusively by rail. Given the small size of oilseed rape seed, leakage from rail cars during transit may occur. The exponential decline in the infestation area and density of populations of oilseed rape with increasing distance from the nearest grain terminal indicates that most seed spillage or dispersal (natural or anthropogenic) occurs in close proximity to the terminals where railway cars are unloaded. Even though oilseed rape has been exported through terminals in Vancouver for decades, the infrequent occurrence of significant populations outside of grain terminal areas 
Y. Yoshimura et al.

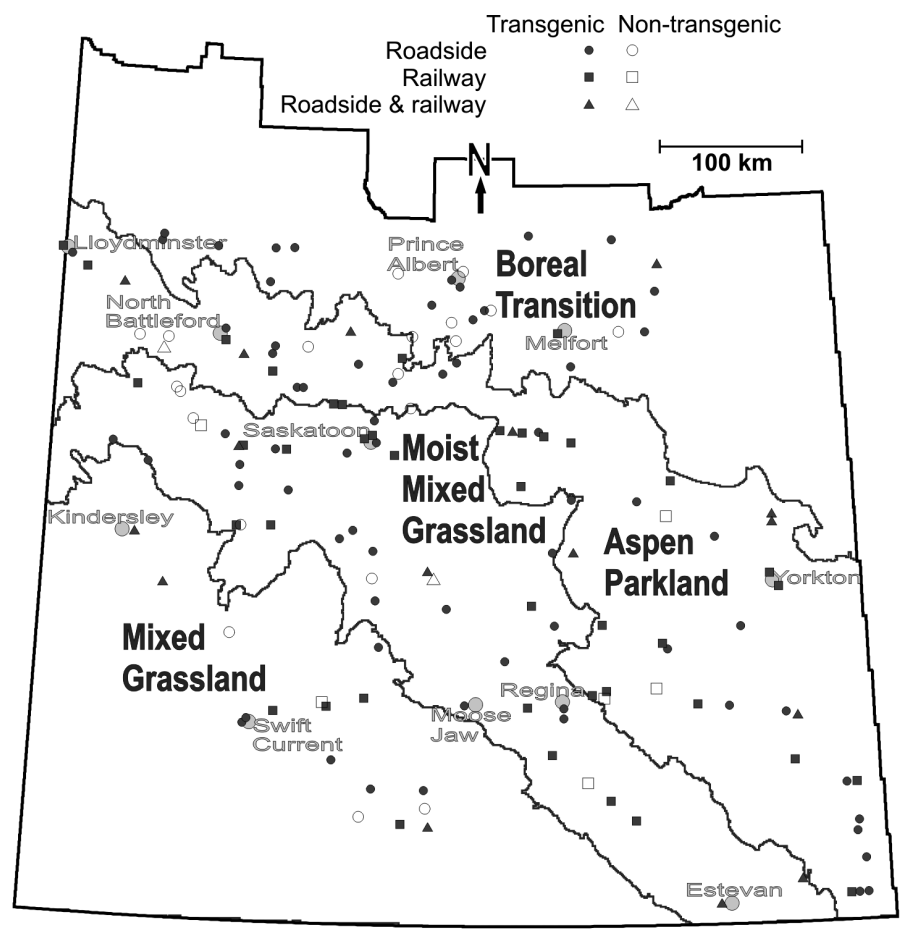

Figure 4. Occurrence of transgenic oilseed rape (glyphosate- or glufosinate-resistant) in ruderal areas (along railways or major roads) across Saskatchewan ecoregions (semi-arid Mixed Grassland to subhumid Aspen Parkland and Boreal Transition) in 2005.

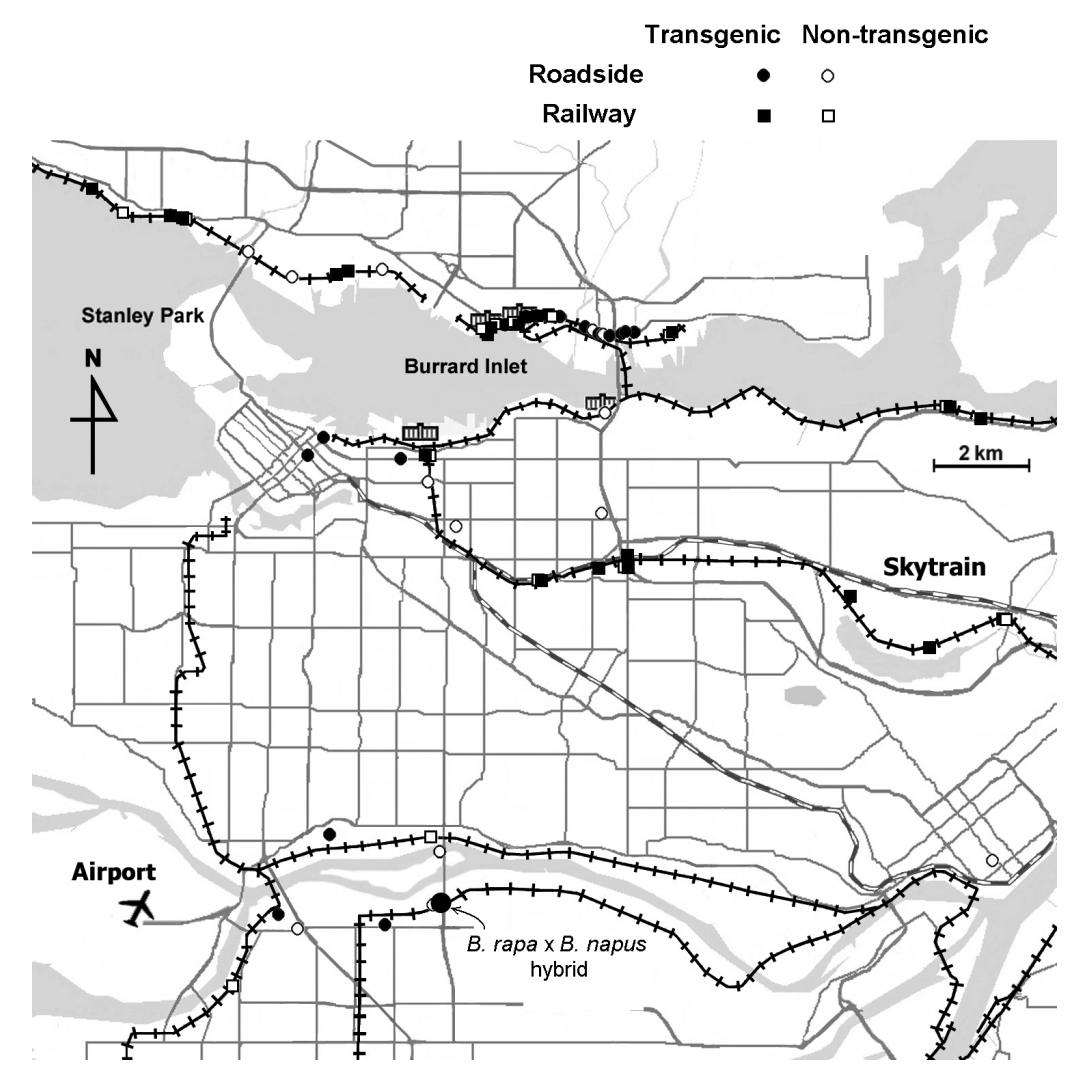

Figure 5. Occurrence of transgenic oilseed rape (glyphosate- or glufosinate-resistant) along railways or roads at the port of Vancouver in 2005. 
Transgenic oilseed rape in ruderal areas

along the shores of Burrard Inlet suggests that the invasiveness of oilseed rape populations in these urban ruderal areas may be relatively low.

In 2004,46 and $31 \%$ of the oilseed rape area in western Canada were planted with glyphosate- and glufosinateHR cultivars, respectively (Beckie et al., 2006). The percentage area of transgenic oilseed rape that year (77\%) is similar to the percentage of sampled oilseed rape plants with either transgene in the 2005 Saskatchewan or Vancouver surveys (about 65\%; Tab. 3). This similarity suggests that most plants sampled in 2005 may have originated from oilseed rape seeds planted or harvested in the recent preceding years. Wide fluctuations in environmental conditions, unsuccessful germination or establishment, predation, etc., can result in the rapid decline of viable oilseed rape seeds on or near the soil surface (Gulden et al., 2003; Légère et al., 2001). The ubiquitous presence of transgenic oilseed rape in these two ruderal areas across Saskatchewan ecoregions reflects the rapid and widespread adoption of transgenic oilseed rape since its introduction in 1995 (Beckie et al., 2006).

The greater frequency of occurrence of oilseed rape with the glyphosate than glufosinate resistance trait in the Vancouver versus Saskatchewan survey may indicate some degree of transgene enrichment through glyphosate selection pressure. It is common for glyphosate to be used to control weeds in areas around grain elevators. Unless tank-mixed with a herbicide having a different mode of action (e.g., 2,4-D), glyphosate-HR oilseed rape would survive such treatment whereas glufosinate-HR oilseed rape would be controlled.

About one-third of the sampled oilseed rape plants in each survey, in which neither transgene was detected, were either imidazolinone-HR (Clearfield $\AA$ cultivars) or non-HR. Imidazolinone resistance was attained by chemical mutagenesis (i.e., non-transgenic). In 2004, $23 \%$ of cultivated oilseed rape comprised non-transgenic cultivars: $15 \%$ were resistant to imidazolinone herbicides and $8 \%$ were non-HR (Beckie et al., 2006).

We had expected to find both transgenes in some oilseed rape plants as a result of intraspecific gene flow. The lack of detection of any double-HR plants in these ruderal areas is in sharp contrast to their frequent occurrence in cropland (Beckie et al., 2003). Such plants would likely have been detected with more intense sampling. A single transgenic B. rapa $\times$ B. napus hybrid found along a road in Vancouver confirms the relatively high probability of hybridization between these two Brassica species. Transgenic B. rapa $\times$ B. napus hybrids have been documented in cropland in Canada previously (Warwick et al., 2003), but not in ruderal areas. Studies are being conducted in Canada to examine the fitness of such hybrids ( $\mathrm{S}$. Warwick and $\mathrm{A}$. Légère, personal communication).

This study complements other ecological studies conducted in transgenic crop-importing countries in Asia. Transgenic oilseed rape plants were found at ports and on roadsides in Japan, likely the result of imported transgenic oilseed rape seeds that were spilled during transportation from port to oilseed-processing facilities (Saji et al., 2005; Aono et al., 2006). Kim et al. (2006) monitored transgenic soybean (Glycine max (L.) Merr.) and corn (Zea mays L.) along roads and in cultivated fields near the port of Incheon, South Korea; a single transgenic corn plant was found.

In western Canada, transgenic volunteer oilseed rape is not currently viewed as being at risk of becoming feral because of the lack of a persistent seed bank, redundant and repetitive control of volunteers in subsequent crops, absence of persistent populations in ruderal areas, and limited weedy relatives with a significant potential for hybridization (Hall et al., 2005); the authors define ferality as the establishment of self-perpetuating populations. Oilseed rape can persist in the seed bank for at least $5 \mathrm{yr}$, based on studies conducted in cropland (Légère et al., 2001), although most recruitment from the seed bank occurs in the first year after oilseed rape (Harker et al., 2006). In Canada, annual weed seed bank dynamics in ruderal areas are largely unknown. In France, winter oilseed rape along roadsides have persisted for at least $8 \mathrm{yr}$ (Pessel et al., 2001); in stochastic modelling, anthropogenic processes (management, seed transport, cropping) and intrinsic processes (local recruitment, seed bank) governed population persistence (Garnier et al., 2006). The persistence of transgenic oilseed rape populations in ruderal areas in Canada has not been scientifically investigated and should be examined in future research.

In Canada, efforts to limit the persistence and spread of transgenic oilseed rape in these ruderal areas will likely not change in the future. The cost borne by municipalities/ counties or railway companies would be a strong disincentive for their management. However, where significant populations exist, more timely and frequent mowing or spot spraying along roads or railways should be considered. Because oilseed rape seed is small and light, seed spillage during seed or field equipment transportation and subsequent dispersal by multiple vectors is a continual problem. To reduce seed spillage along roads, farmers or grain haulers should always cover grain truck boxes and minimize other avenues of seed loss during transportation. Additionally, cleaning seeds off 
headers of combine harvesters when moving among fields will reduce the seed source of ruderal weed populations.

\section{MATERIALS AND METHODS}

From mid-June to mid-August of 2005, leaf samples of oilseed rape or its cultivated (oriental mustard and B. rapa canola) and weedy relatives (dog mustard, wild mustard) were collected at randomly-selected sites in two main ruderal areas of Saskatchewan (Fig. 1): along main line railways (Saskatchewan Highways and Transportation, 2004) and primary roads (highway or grid). The surface of grid roads is elevated above the adjacent land, bordered by steep ditches, and gravelled for year-round traffic. Wild radish was not found at any of the Saskatchewan sites. At some sites, the railway and road were in close proximity (i.e., railway crossings, near grain elevators) and therefore such sites were categorized as 'roadside and railway'. Leaf tissue from usually two plants per species present at each site was sampled. Most plants were in the flowering stage. Samples were kept on dry ice in a cooler until they could be stored in a $-80{ }^{\circ} \mathrm{C}$ freezer. Latitude and longitude coordinates of each site were determined using GPS and recorded. The infestation area of each species at a site was calculated by measuring length and width (if linear) or diameter (if patchy or circular) using a tape measure. Mean plant density at each site was determined by counting plants in one to six $1-\mathrm{m}^{2}$ quadrats, depending upon the size of the infestation area. In addition, mean plant height of each species was determined from measurements of multiple plants per site (number of plants per species listed in the footnote of Tab. 1).

From 18 to 26 May of 2005, leaf samples of the abovementioned species (including wild radish) were collected along railways or roads at the port of Vancouver, similar to the procedure described previously. Dog mustard was not found at any of the Vancouver sites. Data collected were similar to that described previously. In addition, oilseed rape mean density $\left(\mathrm{Y}_{1}\right)$ was regressed against distance ( $\mathrm{x}$ ) from the nearest port grain terminal using the exponential decay model (1); oilseed rape infestation area $\left(\mathrm{Y}_{2}\right)$ was regressed against distance $(\mathrm{x})$ from the nearest port grain terminal using the double exponential decay model (2):

$$
\begin{gathered}
\mathrm{Y}_{1}=a \mathrm{e}^{-b \mathrm{x}} \\
\mathrm{Y}_{2}=a \mathrm{e}^{-b \mathrm{x}}+c \mathrm{e}^{-d \mathrm{x}}
\end{gathered}
$$

where $a$ (plant density) or $a+c$ (infestation area) is the intercept and $b, d$ quantify the slope. Data were fitted to the model using a derivative-free nonlinear regression procedure, provided with the NLIN procedure (Statistical Analysis Systems, 1999). The coefficient of determination $\left(\mathrm{R}^{2}\right)$ that quantifies the goodness of fit was calculated as described by Kvalseth (1985) using the residual sum of squares value from the analysis output.

The glyphosate and glufosinate test strips were used to detect the presence of the herbicide resistance traits in leaf samples. These test strips are available as kits (Trait RUR (Roundup Ready) or Liberty Link LL Flow Test Kits) from Strategic Diagnostics, Newark, Delaware, USA. The RUR trait kit detects the CP4 EPSPS protein produced by the HOR gene, a gene derived from Agrobacterium sp. strain $\mathrm{CP} 4$ and incorporated into glyphosate-HR oilseed rape. The Liberty Link LL trait kit detects the PAT proteins, PAT/pat and PAT/bar, produced by the pat and bar genes, respectively. These were derived from different Streptomyces sp., and incorporated into pedigree-derived and hybrid glufosinate-HR oilseed rape cultivars, respectively. Following the procedure outlined in the kits, approximately $100 \mathrm{mg}$ of leaf tissue was placed in a test tube with $0.75 \mathrm{ml}$ of buffer, a capillary-based strip was inserted in the tube and scored after $5 \mathrm{~min}$ for the presence of two bands on the strip, a control band that tracks the capillary action and a second band that indicates the protein. In a previous study, the herbicide test strips provided the most consistent results compared with herbicide application or PCR amplification of the genes that confer the herbicide resistance (Beckie et al., 2003).

\section{ACKNOWLEDGEMENTS}

We thank Dr. Ginette Séguin-Swartz of Agriculture and Agri-Food Canada in Saskatoon for technical advice and use of laboratory facilities, and Dr. Suzanne Warwick of Agriculture and Agri-Food Canada in Ottawa for AFLP analysis. The senior author of this study was supported by an Organization for Economic Co-operation and Development (OECD) Research Fellowship.

Received August 31, 2006; accepted November 29, 2006.

\section{REFERENCES}

Agriculture and Agri-Food Canada (2003) A national ecological framework for Canada: GIS Data, Agriculture and Agri-Food Canada, Ottawa, Ontario, Canada. http:// sis.agr.gc.ca/cansis/nsdb/ecostrat/gis_data.html

Aono M, Wakiyama S, Nagatsu M, Nakajima N, Tamaoki M, Kubo A, Saji H (2006) Detection of feral transgenic oilseed 
Transgenic oilseed rape in ruderal areas

rape with multiple-herbicide resistance in Japan. Environ. Biosafety Res. 5, doi: 10.1051/ebr:2006017

Beckie HJ, Thomas AG, Légère A, Kelner DJ, Van Acker RC, Meers S (1999) Nature, occurrence, and cost of herbicideresistant wild oat (Avena fatua) in small-grain production areas. Weed Technol. 13: 612-625

Beckie HJ, Hall LM, Warwick SI (2001) Impact of herbicideresistant crops as weeds in Canada. In Proc. Brighton Crop Protection Conf. - Weeds. British Crop Protection Council, Farnham, Surrey, UK, pp 135-142

Beckie HJ, Warwick SI, Nair H, Séguin-Swartz G (2003) Gene flow in commercial fields of herbicide-resistant canola (Brassica napus). Ecol. Appl. 13: 1276-1294

Beckie HJ, Séguin-Swartz G, Nair H, Warwick SI, Johnson E (2004) Multiple herbicide-resistant canola can be controlled by alternative herbicides. Weed Sci. 52: 152-157

Beckie HJ, Harker KN, Hall LM, Warwick SI, Légère A, Sikkema PH, Clayton GW, Thomas AG, Leeson JY, Séguin-Swartz G, Simard M-J (2006) A decade of herbicideresistant crops in Canada. Can. J. Plant Sci. 86: 12431264

Canola Council of Canada (2006) Canadian canola industry market statistics. Canola Council of Canada, Winnipeg, Manitoba, Canada. http://www.canola-council.org/seedexports.html

Garnier A, Deville A, Lecomte J (2006) Stochastic modelling of feral plant populations with seed immigration and road verge management. Ecol. Model. 197: 373-382

Gulden RH, Shirtliffe SJ, Thomas AG (2003) Secondary seed dormancy prolongs persistence of volunteer canola (Brassica napus) in western Canada. Weed Sci. 51: 904-913

Hall L, Topinka K, Huffman J, Davis L, Good A (2000) Pollen flow between herbicide-resistant Brassica napus is the cause of multiple-resistant B. napus volunteers. Weed Sci. 48: 688-694

Hall LM, Good A, Beckie HJ, Warwick SI (2003) Gene flow in herbicide-resistant canola (Brassica napus): the Canadian experience. In Lelley T, Balázs E, Tepfer M, eds, Ecological impact of GMO dissemination in agro-ecosystems, Facultas Verlags-und Buchhandels AG, Austria, pp 57-66

Hall LM, Rahman MH, Gulden RH, Thomas AG (2005) Volunteer oilseed rape - will herbicide-resistance traits assist ferality? In Gressel J, ed, Crop ferality and volunteerism, CRC Press, Boca Raton, Florida, USA, pp 59-79

Harker KN, Clayton GW, Blackshaw RE, O'Donovan JT, Johnson EN, Gan Y, Holm FA, Sapsford KL, Irvine RB, Van Acker RC (2006) Persistence of glyphosate-resistant canola in western Canadian cropping systems. Agron. J. 98: 107-119

Kim CG, Yi H, Park S, Yeon JE, Kim DY, Kim DL, Lee KH, Lee TC, Paek IS, Yoon WK, Jeong SC, Kim HM (2006) Monitoring the occurrence of genetically modified soybean and maize around cultivated fields and at a grain receiving port in Korea. J. Plant Biol. 49: 218-223
Kvalseth TO (1985) Cautionary note about $R^{2}$. Am. Stat. 39: 279-285

Leeson JY, Thomas AG, Brenzil CA (2003) Saskatchewan weed survey of cereal, oilseed and pulse crops in 2003, Weed Survey Series Publication 03-1, Agriculture and Agri-Food Canada, Saskatoon Research Centre, Saskatoon, Saskatchewan, Canada

Leeson JY, Thomas AG, Hall LM, Brenzil CA, Andrews T, Brown KR, Van Acker RC (2005) Prairie weed surveys of cereal, oilseed and pulse crops from the 1970s to the 2000s, Weed Survey Series Publication 05-1, Agriculture and AgriFood Canada, Saskatoon Research Centre, Saskatoon, Saskatchewan, Canada

Légère A, Simard M-J, Thomas AG, Pageau D, Lajeunesse J, Warwick SI, Derksen DA (2001) Presence and persistence of volunteer canola in Canadian cropping systems. In Proc. Brighton Crop Protection Conf. - Weeds. British Crop Protection Council, Farnham, Surrey, UK, pp 143-148

Pessel FD, Lecomte J, Emeriau V, Krouti M, Messean A, Gouyon PH (2001) Persistence of oilseed rape (Brassica napus L.) outside of cultivated fields. Theor. Appl. Genet. 102: $841-846$

Saji H, Nakajima N, Aono M, Tamaoki M, Kubo A, Wakiyama S, Hatase Y, Nagatsu M (2005) Monitoring the escape of transgenic oilseed rape around Japanese ports and roadsides. Environ. Biosafety Res. 4: 217-222

Saskatchewan Highways and Transportation (2004) Saskatchewan rail network map, Department of Highways and Transportation. http://www.highways.gov.sk.ca/docs/ maps/railnetwork_04.pdf

Simard M-J, Légère A, Séguin-Swartz G, Nair H, Warwick S (2005) Fitness of double vs. single herbicideresistant canola. Weed Sci. 53: 489-498

Snow AA, Andersen B, Jørgensen RB (1999) Costs of transgenic herbicide resistance introgressed from Brassica napus into weedy Brassica rapa. Mol. Ecol. 8: 605-615

Statistical Analysis Systems (1999) SAS/STAT user's guide, version 8, Statistical Analysis Systems Institute, Inc., Cary, North Carolina, USA

Statistics Canada (2005) November estimate of production of principal field crops, Canada, 2005, Field Crop Reporting Series 84:8, Catalogue Number 22-002-XPB, Statistics Canada, Ottawa, Ontario, Canada

Warwick SI (2005) Past/future research perspective from Canada: living with GM crops in agriculture, Gene Flow in Plants and Microorganisms Initiative Workshop, Biotechnology and Biological Sciences Research Council (BBSRC), 23-24 June 2005 Symposium Abstract, London, UK Warwick SI, Simard M-J, Légère A, Beckie HJ, Braun L, Zhu B, Mason P, Séguin-Swartz G, Stewart CN (2003) Hybridization between transgenic Brassica napus L. and its wild relatives: Brassica rapa L., Raphanus raphanistrum L., Sinapis arvensis L., and Erucastrum gallicum (Willd.) O.E. Schulz. Theor. Appl. Genet. 107: 528-539 